3. The growth rate of young rats, given the high-protein and the low-protein moieties of the diet on alternate days was less than that of pair-fed, litter-mate control animals consuming both moieties together.

4. Intermittent protein feeding likewise impaired lactational capacity of the mothers and retarded recovery of the haemoglobin content of the blood after experimentally induced anaemia.

5. Fertility was not noticeably affected by intermittent feeding of protein.

6. The less satisfactory condition of the young of the mothers given protein intermittently remained clearly manifest after weaning, when young of both groups were raised on a normal stock diet.

\title{
REFERENCES
}

Cuthbertson, D. P., McCutcheon, A. \& Munro, H. N. (1940). Biochem. F. 34, 1002.

Geiger, E. (r947). F. Nutr. 34, 97.

Geiger, E. (1948a). F. Nutr. 36, 81 3.

Geiger, E. (1948b). Science, 108, 42.

Hahn, P. F., Bale, W. F., Hettig, R. A., Kamen, M. D. \& Whipple, G. H. (1939). F. exp. Med. 70, 443. Henry, K. M. \& Kon, S. K. (1945-6). F. Dairy Res. 14, 330.

Luyken, R. \& Luyken-Koning, F. W. M. (1955). Docum. Med. geogr. trop. 7, 315.

Mahalanobis, S. K. \& Roy, R. N. (1952). Indian F. Physiol. allied Sci. 6, I20.

Orten, J. M. \& Orten, A. U. (1946). F. Nutr. 3I, 765.

Steenbock, H. \& Nelson, E. M. (1923). F. biol. Chem. 56, 355 .

\section{Excretion of chromium sesquioxide and polyethyleneglycol by dairy cows}

\author{
By J. L. CORBETT, J. F. D. GREENHALGH, P. E. GWYNN \\ AND D. WALKER \\ Rowett Research Institute, Bucksburn, Aberdeenshire
}

(Received I 3 Fanuary 1958)

The concentration of the inert feed-marker chromium sesquioxide $\left(\mathrm{Cr}_{2} \mathrm{O}_{3}\right)$ in the faeces of cattle and sheep normally varies considerably during the course of $24 \mathrm{~h}$, although it had been administered regularly for long periods mixed with the concentrates fed to the animals as a part of their ration (Kane, Jacobson \& Moore, 1952; Bloom, Jacobson, Allen, McGilliard \& Homeyer, 1957) or in gelatin capsules (Hardison \& Reid, 1953; Hardison, Engel, Linkous, Sweeney \& Graf, 1956; Pigden \& Brisson, I956; Raymond \& Minson, I955). In consequence estimates of food digestibility or of faeces output derived from the concentration of $\mathrm{Cr}_{2} \mathrm{O}_{3}$ in a single defaecation may be erroneous.

Sperber, Hydén \& Ekman (I953) suggested that a polyethyleneglycol (PEG) of high molecular weight (4000) could be used for tracing the flow of water and solutes from the reticulo-rumen into the omasum, and this technique has been used by Oyaert (1955). 
Unlike $\mathrm{Cr}_{2} \mathrm{O}_{3}$ and most other substances used as markers, PEG is readily soluble in water but Sperber et al. (1953) could not detect any absorption from the gut or any effects on rumen micro-organisms. Hydén (1956b) found that when single doses of PEG were administered directly by fistula into the rumen or abomasum of cattle (roo$200 \mathrm{~g}$ doses) and sheep ( $15-20 \mathrm{~g}$ doses) the mean recovery in faeces was $93 \%$ (range $82 \cdot 9-100 \cdot 6 \%$ ). He suggested that the apparent losses of PEG were due to some destruction of the material during its passage through the digestive tract. Corbett, Miller, Clarke \& Florence (I956, and unpublished observations) gave grass-meal cubes containing $12 \cdot 2 \%$ PEG and $7 \cdot 2 \% \mathrm{Cr}_{2} \mathrm{O}_{3}$ to four grazing dairy cows at the rate of $200 \mathrm{~g} / \mathrm{cow} /$ day. All faeces produced in a total of eighteen 5-day periods were collected in bags attached to harnesses worn by the animals. Recoveries of PEG were low and very variable, averaging $56.9 \%$ (range $35.5-92.9 \%$ ), but the mean $\mathrm{Cr}_{2} \mathrm{O}_{3}$ recovery was Iог. $9 \%$ with a range for individual cow-periods of $89 \cdot 4-117 \cdot 2 \%$ corresponding to that obtained in similar circumstances by Lancaster, Coup \& Percival (1953). Results of experiments where varying amounts of PEG were mixed with faeces suggested that the low recoveries of PEG in the grazing experiment were due in part to difficulties in determining the low concentrations of PEG, $50-80 \mathrm{mg} / \mathrm{ro0} \mathrm{g}$ fresh faeces, and that satisfactory results might be obtained if larger amounts of marker were administered.

The experiment now reported was designed to test the suitability of PEG as a marker in digestibility studies and to assess its merits relative to those of $\mathrm{Cr}_{2} \mathrm{O}_{3}$.

\section{EXPERIMENTAL}

Six lactating Ayrshire cows were confined in metabolism stalls for a period of 3 weeks and faeces and urine were collected separately with apparatus similar to that described by Balch, Bartlett \& Johnson (195I). Their ration consisted of baled artificially dried grass only, fed at 07.30 and $17.00 \mathrm{~h}$ in standard amounts which approximately met the conventional starch-equivalent requirements of each animal (Woodman, 1954). Three of the cows were given an artificially dried grass (S) prepared from herbage cut in June and the other three a dried grass (A) prepared from herbage cut from the same field in October of the same year. Dried grass $\mathrm{S}$ contained $\mathrm{I} \cdot \mathrm{x} \% \mathrm{\%}$ crude protein, $27.0 \%$ crude fibre and $5.6 \%$ ash, and dried grass A contained $\mathrm{I} 6 . \mathrm{I} \%$ crude protein, $24 . \mathrm{I} \%$ crude fibre and $8.9 \%$ ash, all expressed on a dry-matter basis.

\section{Administration of markers}

A PEG (Oxirane Ltd, Manchester) with an average molecular weight of $3000-4000$ was used; it was similar to the polymer used by Sperber et al. (1953).

Preparation and administration of gelatin capsules of the markers to provide daily doses per cow of ${ }_{15} \mathrm{~g} \mathrm{Cr}_{2} \mathrm{O}_{3}$ and $25 \mathrm{~g}$ PEG, the amounts necessary to give readily measurable concentrations in faeces, presented considerable practical difficulties, and so the markers were mixed with dried-grass meal which was then cubed. The cubes contained per $100 \mathrm{~g} 9.00 \pm 0.2 \mathrm{I}$ moisture, $7.08 \pm 0.30 \mathrm{~g} \mathrm{Cr}_{2} \mathrm{O}_{3}$, and $12.54 \pm 0.10 \mathrm{~g}$ PEG. They were offered in Polythene bowls twice daily before milking (at 06.00 and $\mathrm{I} 6.00 \mathrm{~h}$ ) throughout the experiment at rates of $100 \mathrm{~g} /$ feed to one cow in each ration 
group (providing daily $\mathrm{I}_{4} \cdot 2 \mathrm{~g} \mathrm{Cr}_{2} \mathrm{O}_{3}$ and $25 \cdot \mathrm{I} \mathrm{gEG}$ ) and $400 \mathrm{~g} /$ feed $\left(56 \cdot 6 \mathrm{~g} \mathrm{Cr}_{2} \mathrm{O}_{3}\right.$ and I00. $3 \mathrm{~g}$ PEG daily) to the other four cows. The bowls were usually licked clean and unconsumed residues were negligible.

\section{Collection and sampling of faeces}

Throughout the experiment the cattle wore harness, urine separators and faecescollection bags which were usually emptied twice daily. For 5 days during the last week samples of the faeces produced by each cow were bulked in amounts proportional to the weights excreted, and subsequently subsampled for analysis.

During the $24 \mathrm{~h}$ immediately preceding the 5 -day collection period (I), single defaecations from each cow were all separately collected when voided, weighed and analysed. During the $24 \mathrm{~h}$ immediately following the 5 -day period (2), faeces voided by the four cows that received the higher dose of markers were separately collected every $4 \mathrm{~h}$, weighed, and analysed.

\section{Chemical methods}

Chromium sesquioxide. The method of analysis was similar to that described by Schürch, Lloyd \& Crampton (1950).

Polyethyleneglycol. Initially a colorimetric method of analysis (Schaffer \& Critchfield, 1947 $a$ ) was used. A modification of Hydén's (1956 $a$ ) more rapid turbidimetric method was found to give results consistent with those obtained colorimetrically and was adopted in later work. With both methods the feed or faeces samples containing PEG were first diluted ten or more times with water, and protein and sulphate were then removed from the aqueous extract as described by Hydén (1956a). Turbidity develops on adding a reagent consisting of trichloroacetic acid $(30 \%, \mathrm{w} / \mathrm{v})$ and barium chloride $(5 \%, \mathrm{w} / \mathrm{v})$. Measurements of turbidity made in a photoelectric colorimeter, as proposed by Hydén ( $1956 a$ ), showed considerable variability and were unreliable, but satisfactory repeatable results were obtained with a nephelometer. The reagent $(5 \mathrm{ml}$.) was rapidly and carefully mixed with $5 \mathrm{ml}$. of protein- and sulphate-free aqueous extract of faeces in a nephelometer tube which was then placed immediately in the instrument. A straight-line relationship was found between maximum nephelometer reading and PEG concentration over the range $1.0-5.0 \mathrm{mg} \mathrm{PEG} / \mathrm{I} 00 \mathrm{ml}$. The lowest concentration that could be determined with accuracy was $0.5 \mathrm{mg} P E G / 100 \mathrm{ml}$. Nephelometer readings reached a maximum after I-6 min, depending on PEG concentration, and then declined. Freshly made PEG solutions were used in the preparation of standard curves, since stored solutions, especially those exposed to daylight, tended to give low values.

\section{RESULTS}

Results of analyses of bulked samples of faeces obtained during the 5 -day collection period are presented in Table I. The quantities of dried grass fed varied according to the live weight and milk production of the animal. Figures for dry-matter consumption include the small quantities of grass dry matter in the marker cubes. For each dried grass there was good agreement between cows in coefficients of apparent digestibility 
of dry matter. Recoveries of $\mathrm{Cr}_{2} \mathrm{O}_{3}$, expressed as a percentage of the total amounts consumed, were rather variable for cows consuming dried grass A but averaged $100.0 \%$; they averaged $94.4 \%$ for the cows consuming dried grass S. Regardless of

Table I. Rations used, apparent digestibility of the ration dry matter, and chromium sesquioxide and polyethyleneglycol given and recovered in faeces of cows during a 5-day conventional digestibility trial

\begin{tabular}{|c|c|c|c|c|c|c|c|}
\hline \multirow{7}{*}{$\begin{array}{c}\text { Cow no. } \\
268 \\
264 \\
265\end{array}$} & \multirow{2}{*}{\multicolumn{2}{|c|}{ Dried grass consumed }} & \multirow{4}{*}{$\begin{array}{c}\text { Apparent } \\
\text { digestibility } \\
\text { of dry matter } \\
(\%)\end{array}$} & \multicolumn{4}{|c|}{ Marker } \\
\hline & & & & \multirow{2}{*}{\multicolumn{2}{|c|}{ Given (g/day) }} & \multirow{2}{*}{\multicolumn{2}{|c|}{$\begin{array}{c}\text { Recovered in faeces } \\
(\%)\end{array}$}} \\
\hline & \multirow[b]{2}{*}{ Type* } & \multirow{2}{*}{$\begin{array}{l}\text { Amount } \\
\text { (lb. dry } \\
\text { matter/day) } \dagger\end{array}$} & & & & & \\
\hline & & & & $\mathrm{Cr}_{2} \mathrm{O}_{3}$ & PEG & $\mathrm{Cr}_{2} \mathrm{O}_{3}$ & PEG \\
\hline & $\mathrm{S}$ & $20 \cdot 9$ & $75^{\circ} 9$ & $14 \cdot 2$ & $25 \cdot 1$ & $94: 4$ & $96 \cdot 2$ \\
\hline & $\mathrm{S}$ & $27 \cdot 3$ & $75 \cdot 7$ & $56 \cdot 6$ & $100 \cdot 3$ & $90 \% 7$ & $94 \cdot 6$ \\
\hline & $\mathrm{S}$ & $25 \cdot 6$ & $75 \cdot 1$ & $56 \cdot 6$ & $100 \cdot 3$ & $98 \cdot I$ & $97^{\prime} \mathbf{I}$ \\
\hline & & Mean & $75 \cdot 6$ & - & - & $94 \cdot 4$ & $96 \cdot 0$ \\
\hline I 89 & $A$ & $23 \cdot 8$ & $71 \cdot 5$ & $x_{4} \cdot 2$ & $25 \cdot 1$ & $112: 2$ & $76 \cdot 8$ \\
\hline 216 & A & $23 \cdot 2$ & $71 \cdot 3$ & $56 \cdot 6$ & $100 \cdot 3$ & $99^{\circ} \mathbf{I}$ & $89 \cdot 0$ \\
\hline \multirow[t]{2}{*}{224} & A & 25.0 & $70 \cdot 6$ & $56 \cdot 6$ & $100 \cdot 3$ & 88.7 & $8 I \cdot 0$ \\
\hline & & Mean & $7 I \cdot I$ & - & - & $100 \cdot 0$ & $82 \cdot 3$ \\
\hline
\end{tabular}

* Dried grasses S and A were prepared from herbages cut at different times from the same field (see p. 267).

+ Includes the grass dry matter consumed in marker cubes, approximately $0.2 \mathrm{lb}$. (cows 268 , I 89 ) or I. 3 lb. (cows $264,265,216,224$ ).

Table 2. Total dry matter, polyethyleneglycol and chromium sesquioxide $(g)$ excreted in faeces by cows during two $24 \mathrm{~h}$ periods (I and 2) ( $A$ ), and variability between individual defaecations in period $\mathrm{I}(B)$

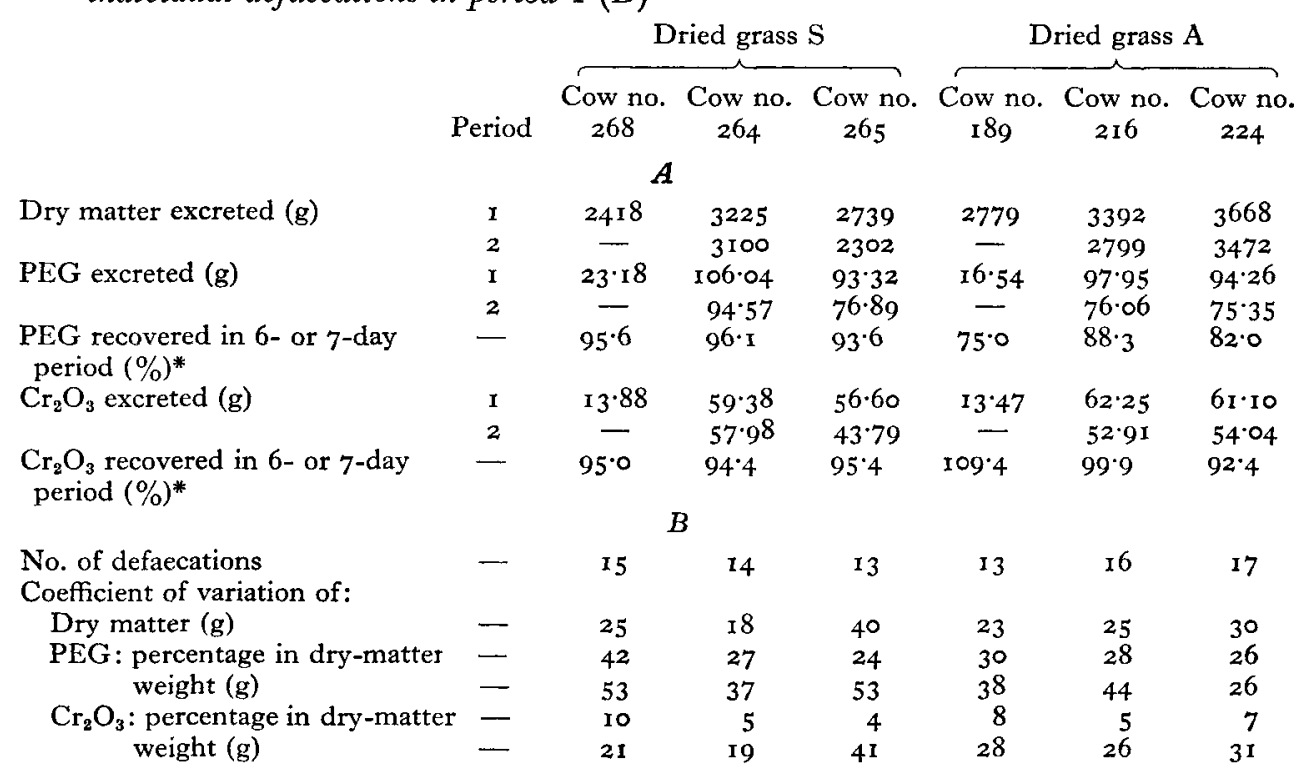

* Total weights of PEG or $\mathrm{Cr}_{2} \mathrm{O}_{3}$ excreted in 5-day period (Table $\mathrm{I}$ ) together with weights of markers excreted in $24 \mathrm{~h}$ period $\mathrm{I}$ (cows $268, \mathrm{I} 89 ; 6$ days) or $\mathrm{I}$ and 2 (cows $264,265,2 \mathrm{16}, 224 ; 7$ days) expressed as a percentage of total amounts consumed in corresponding periods. 
dose level the PEG recoveries from cows given dried grass A were low, averaging $82.3 \%$. Recoveries from the other three cows were consistently higher, averaging $96.0 \%$. Samples of urine were taken regularly from all cows but no traces of PEG were detected.

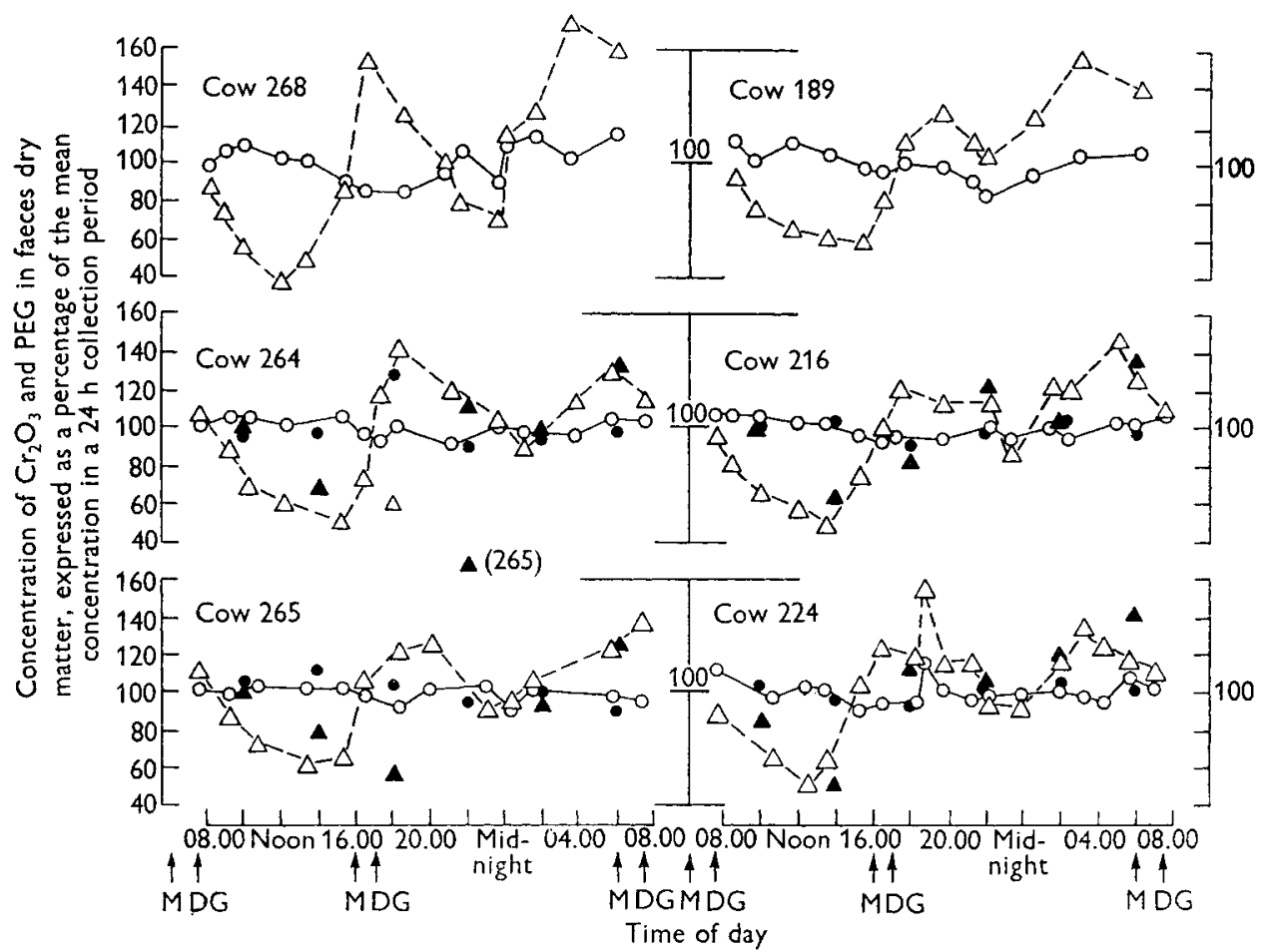

Fig. $\mathrm{x}$. Concentration of $\mathrm{Cr}_{2} \mathrm{O}_{3}$ and PEG in the dry matter of samples of faeces from individual cows expressed as a percentage of

$$
\begin{aligned}
& \text { total weight of marker }(\mathrm{g}) \text { recovered in } 24 \mathrm{~h} \\
& \text { total weight of faeces dry matter }(\mathrm{g}) \text { in } 24 \mathrm{~h}
\end{aligned} \text {, taken as } \mathrm{I} \text { oo. }
$$

$0-0, \mathrm{Cr}_{2} \mathrm{O}_{3} ; \Delta_{-}-\Delta, \mathrm{PEG}$ (both from analyses of faeces collected when voided in $24 \mathrm{~h}$ period $\mathrm{I}$ ), - $\mathrm{Cr}_{2} \mathrm{O}_{3} ; \wedge \mathrm{PEG}$ in 4 -hourly faeces collect,ons in $24 \mathrm{~h}$ period 2,6 days later. Arrows show the times of giving cubes containing markers (M) and the dried-grass ration (DG).

Results of analyses of faeces obtained during periods $\mathrm{I}$ and 2 (see p. 268) are presented in Table 2. There was some variation in the total weights of markers excreted but, when combined with the results obtained in the 5-day period, they did not greatly alter the estimates of total recoveries of markers. Coefficients of variation for the concentrations and weights of the two markers in individual defaecations were calculated from the results obtained in period $\mathrm{I}$. Variations in the concentration of PEG in faeces dry matter $(\mathrm{g} / \mathrm{I} 00 \mathrm{~g})$ were large and considerably greater in magnitude than those of $\mathrm{Cr}_{2} \mathrm{O}_{3}$ concentration. The weight of $\mathrm{PEG}$ in each defaecation varied with the weight of faeces voided and with PEG concentration. Variations in the weight of $\mathrm{Cr}_{2} \mathrm{O}_{3}$ were caused mainly by variations in faeces output. 
The concentrations of the two markers in each lot of faeces are shown in Fig. I where, for each cow, they are expressed as a percentage of

$$
\frac{\text { total weight of marker }(\mathrm{g}) \text { recovered in } 24 \mathrm{~h}}{\text { total weight of faeces dry matter }(\mathrm{g}) \text { in } 24 \mathrm{~h}} \text {, taken as } 100 \text {. }
$$

The general pattern of marker excretion in period I was the same in all the cows. With allowance for errors due to less frequent collection of faeces the pattern was repeated in the results obtained 5 days later in period 2 for the four cows studied. $\mathrm{Cr}_{2} \mathrm{O}_{3}$ and PEG excretion curves showed marked differences. Concentrations of $\mathrm{Cr}_{2} \mathrm{O}_{3}$ rarely varied by more than $10 \%$ from the $24 \mathrm{~h}$ weighted means. There were two low and two high points in PEG concentrations which showed maximum variations of $40-60 \%$ from the weighted means. The high points occurred Io- $14 \mathrm{~h}$ after the times of administration of the marker and bore little relation to $\mathrm{Cr}_{2} \mathrm{O}_{3}$ values.

\section{DISCUSSION}

\section{Marker recoveries}

The excellent measure of agreement between digestibility figures suggests that variations in recoveries of markers during the 5 -day collection period cannot be ascribed to errors in the trial technique. Other workers have reported considerable variations in the recoveries of $\mathrm{Cr}_{2} \mathrm{O}_{3}$ from ruminants; for example Lancaster et al. (1953) obtained almost exactly $100 \%$ recoveries from three cows over a period of 40 days, but recoveries in the constituent 5 -day periods varied between 90 and I $_{19} \%$. Estimates of recoveries in the present experiment were based on figures for the average composition of the marker cubes consumed, but the amounts of $\mathrm{Cr}_{2} \mathrm{O}_{3}$ they contained were found by analysis to be rather variable, the standard deviation from the mean of 7.08 being \pm 0.30 . This variability would be sufficient to account for a considerable part of the variations in $\mathrm{Cr}_{2} \mathrm{O}_{3}$ recoveries and it may have arisen because this dense material (sp.gr. $5 \cdot 2$ ) settled out of the grass meal during or after mixing and before cubing.

The amounts of PEG in different samples of the cubes were relatively constant, averaging $12 \cdot 54 \pm 0.10 \%$, and it is unlikely that the small variation was responsible for the variable $\mathrm{PEG}$ recoveries. In addition, cows consuming dried grass A consistently gave markedly lower recoveries of $\mathrm{PEG}$, but not of $\mathrm{Cr}_{2} \mathrm{O}_{3}$, than those consuming dried grass S. Since no cow excreted more than $97.1 \%$ of the PEG doses it appears that losses of PEG occurred ( 1 ) by absorption from the alimentary tract, (2) by destruction in the alimentary tract, or (3) during collection or analysis of faeces.

(1) Shaffer \& Critchfield (1947 $b$ ) and Shaffer, Critchfield \& Carpenter (1948) have shown that PEG entering the blood stream is efficiently excreted by the kidneys though small amounts of the polymers of lower molecular weight (400 and 1000) may be metabolized in the body. It is unlikely that the cows in the present experiment absorbed large amounts of PEG into the blood stream for none was ever detected in their urine. Hueper ( I94I) reported that macromolecular substances such as polyvinyl alcohol produced vascular lesions (atheroma) when fed to guinea-pigs. It was considered that PEG, if absorbed into the blood stream, might have similar effects, and a 
cow used in an earlier experiment (Corbett et al. 1956) was slaughtered when it had consumed $25 \mathrm{~g}$ PEG daily for a period of I I weeks. A section of the aorta was examined histologically but no abnormalities were observed (L. G. Donald, personal communication).

(2) Hydén (I956b) concluded that PEG was destroyed to a limited extent in the alimentary tract and that the losses increased as time of passage increased. It is not known whether the rate of passage of digesta was slower in cows receiving dried grass A, yielding the lowest PEG recoveries, than in the other cows, but this is unlikely, since the time intervals between marker doses and peak PEG concentrations in faeces for the two groups were approximately the same. Recoveries of PEG added to faeces were not affected by incubation for some days at $37^{\circ}$ (Miller \& Corbett, unpublished observations). The effects of PEG upon rumen micro-organisms were also investigated by the technique described by Eadie, Mann \& Oxford (1956). It was found (Eadie \& Mann, personal communication) that neither bacteria nor protozoa were affected by concentrations of PEG in the range $0 . \mathrm{I}-\mathrm{I} \cdot 0 \mathrm{~g} / \mathrm{I} 00 \mathrm{ml}$. medium. This result agrees with the findings of Sperber et al. (I953).

(3) It is unlikely that the apparent PEG losses were due to incomplete collection of faeces or faulty sampling procedures, and there was no possibility of leaching of PEG from faeces during handling. Experiments on the recovery of PEG added to faeces, extending those carried out earlier (Corbett et al. 1956), strongly suggested that varying amounts of PEG were lost during the preliminary stages of analysis. Recoveries were usually low if, before removal of protein and sulphate, the faeces samples were diluted less than ten times with water, but in some instances, especially with faeces from grazing cattle, $100 \%$ recoveries were not achieved even after dilution to measurable PEG limits. Full recoveries were always obtained when the PEG was added to a faeces extract after removal of protein and sulphate, and it appeared that a major part of the losses observed occurs when these substances are precipitated. However, there was no obvious relationship between the protein content of the faeces samples and the amounts of PEG lost; blood plasma added to aqueous solutions of PEG did not affect determinations. Hydén ( $1956 b$ ) obtained good recoveries of PEG in in vitro trials but these were all done with faeces derived from winter rations. In our experiments also, recoveries were usually good from the faeces of cattle fed on winter rations (varying proportions of hay, silage, straw, turnips, distiller's grains and concentrates) but there were anomalous results with some samples and it was observed that these, like 'grass' faeces, formed a fairly stable colloid-like suspension with water.

\section{Variations in marker concentrations}

Irregularities in feeding pattern and behaviour enhance irregularities in the excretion of markers by cattle and sheep (Balch, Reid \& Stroud, 1957; Lambourne, I957) and, as shown by Hardison \& Reid (1953) and Raymond \& Minson (1955), faecal $\mathrm{Cr}_{2} \mathrm{O}_{3}$ concentrations are more variable in grazing than in hand-fed animals. In this indoor experiment management of the cows followed a regular routine and it is probably for this reason that they all showed remarkably similar marker-excretion patterns 
(Fig. I), but although variations in faecal $\mathrm{Cr}_{2} \mathrm{O}_{3}$ concentrations were, as might be expected, fairly small, PEG concentrations unexpectedly varied very widely.

At first sight it appears that the physical properties of PEG, its low sp.gr. (I·2) and solubility in water, are more satisfactory than those of $\mathrm{Cr}_{2} \mathrm{O}_{3}$ which, with a sp.gr. of $5 \cdot 2$, might tend to settle out of digesta and, as suggested by Barnicoat (1945) and Crampton \& Lloyd (195I), give rise to local concentrations and retention in the gut. Hoelzel (1930) reported that the rate of passage of various inert materials through the digestive tract was more or less proportional to their sp.gr. (range $0.9-\mathrm{I} 9 \cdot 2$ ) but the test materials were given as fairly large-sized beads, discs or rods. $\mathrm{Cr}_{2} \mathrm{O}_{3}$, used commercially as a paint pigment, is an impalpably fine powder and Chanda, Clapham, McNaught \& Owen (I95I) stated that it readily remains in suspension in gut contents. The results of this experiment suggest that the density of a marker when it is given in a finely divided state is relatively unimportant amongst whatever factors determine the pattern of its excretion and that, provided it becomes well mixed with digesta, sedimentation in the stomach or elsewhere (e.g. the caecum) does not occur to any appreciable extent. These conclusions are supported by results reported by other workers. Raymond \& Minson (1955) found no evidence of a decrease in the range of the diurnal variation in faeces when $\mathrm{Cr}_{2} \mathrm{O}_{3}$ was given by drenching as a stable suspension (sp.gr. $\mathrm{I} \cdot 03$ ) instead of in capsules, and Lambourne ( 1957 ) found that the pattern of excretion of monastral blue (sp.gr. $\mathrm{I} \cdot \mathrm{I}$ ) was similar to that of $\mathrm{Cr}_{2} \mathrm{O}_{3}$. In addition Corbin \& Forbes ( $195 \mathrm{I}$ ) found diurnal variations in the concentration of the oil-soluble dye, anthraquinone violet, in the faeces of lambs given regular standard doses of this substance.

Even if a marker were well mixed with the contents of the alimentary tract variable excretion would occur if feed constituents of different digestibilities became stratified in passage through the gut or absorption activity varied at different times of the day, i.e. a high marker concentration in a sample of faeces would correspond to the passage of a well-digested feed fraction. These possibilities have been suggested by Bloom et al. (1957) in order to account for results obtained with dairy cows and by Moore (I957) in order to explain why pigs excreted $\mathrm{Cr}_{2} \mathrm{O}_{3}$ unevenly although it was very thoroughly mixed with the whole of the diet. If diurnal variations in digestibility were the only cause of variations in marker excretion, the patterns of $\mathrm{Cr}_{2} \mathrm{O}_{3}$ and $\mathrm{PEG}$ excretion would be identical. Furthermore, if dried grass $\mathrm{S}$, which gave digestibility coefficients for dry matter of approximately $70 \%$, is taken as an example, those lots of faeces that contained amounts of PEG $50 \%$ greater than the weighted mean concentrations would indicate a dry-matter digestibility of $84 \%$, and those containing only half the mean PEG concentration a $50 \%$ digestibility. Consequently, it is unlikely that variations in digestibility accounted for more than a small part of the variations in the excretion of PEG and probably also of $\mathrm{Cr}_{2} \mathrm{O}_{3}$.

It is probable that variable marker excretion by ruminants arises mainly from uneven clearance from the stomachs, particularly the reticulo-rumen. Marked variations in $\mathrm{Cr}_{2} \mathrm{O}_{3}$ concentrations have been found by one of us (J.F.D.G.) in samples of digesta taken from the duodenum of a sheep dosed with capsules containing this marker, larger variations, in fact, than those found in the resultant faeces. Balch et al. 
(1957) found greater variations in $\mathrm{Cr}_{2} \mathrm{O}_{3}$ concentrations in digesta passing through the reticulo-omasal orifice than in faeces and suggested that digesta undergo some mixing after leaving the reticulo-rumen.

When markers are given in a concentrated form once or twice daily, uneven excretion probably arises in the first instance from the rapid passage of a portion of the dose before thorough mixing with digesta has been achieved. This was shown by the results of Balch et al. (1957), and Lambourne (1957) found that match-head sized specks of $\mathrm{Cr}_{2} \mathrm{O}_{3}$ had progressed two-thirds along the length of the small intestine of sheep only $\mathrm{I}_{2} \frac{\mathrm{h}}{\mathrm{h}}$ after dosing. Subsequently, after some degree of mixing, the relatively continuous process of feeding would probably reduce progressively marker concentrations in the rumen and outflowing digesta in the intervals between doses. Thus Pigden $\&$ Brisson (1956) and Brisson, Pigden \& Sylvestre (1957) found that sheep and cattle excreted $\mathrm{Cr}_{2} \mathrm{O}_{3}$ very evenly when it was administered in six equal daily doses, one every $4 \mathrm{~h}$. In itself neither of these possibilities fully explains the difference between the excretion patterns of $\mathrm{Cr}_{2} \mathrm{O}_{3}$ and PEG, and it appears that it must be explained by differences in the distribution of the two markers amongst digesta. Balch et al. (1957) found that once the $\mathrm{Cr}_{2} \mathrm{O}_{3}$ had become mixed with the contents of the reticulo-rumen the amount present there declined at much the same rate as the dry matter of the contents. It is suggested, therefore, that $\mathrm{Cr}_{2} \mathrm{O}_{3}$ behaves in a manner similar to that of dry matter in its passage through the gut. As suggested by King \& Moore (1957) $\mathrm{Cr}_{2} \mathrm{O}_{3}$ may, in fact, be adsorbed on to feed particles or lodge in pits and crevices in fibrous digesta. PEG, on the other hand, is readily soluble in water and after a dose is administered its distribution within the reticulo-rumen probably soon parallels that of water. The greatest amounts of PEG would therefore be present in the liquid phase of the digesta and, as shown by Schalk \& Amadon (1928), it is this portion that is least delayed in its passage along the gut. Consequently, PEG would tend to be cleared much more rapidly than $\mathrm{Cr}_{2} \mathrm{O}_{3}$ from the reticulo-rumen and, after water resorption, it would appear in the faeces dry matter in widely varying concentrations. These hypotheses will be tested experimentally.

It appears that reference substances should be chosen with care and perhaps 'tailored' to fit the requirements of the experiment. For example the fate of Clostridium welchii introduced into the rumen of lambs was studied by Bullen, Scarisbrick \& Maddock (1953) with the aid of a finely divided alumina (tagged with radioactive iridium) with suspension properties similar to those of the organism. It is unlikely that PEG would be a satisfactory marker of dry matter, even if the analytical technique were modified to give consistent recoveries, but it does appear to be a valuable indicator of the flow of water and solutes through the alimentary tract, as originally suggested by Sperber et al. (r953). Probably no single marker can exactly follow the passage of 'dry matter', a convenient term for a highly variable entity in which each constituent will tend to show individual behaviour patterns in passage. Thus diurnal variations in the concentrations of lignin (Kane et al. 1952) and plant pigments (Hardison, Linkous \& Ward, x957) in cattle faeces have been reported. $\mathrm{Cr}_{2} \mathrm{O}_{3}$ appears to be the most generally satisfactory marker of dry matter yet tested and difficulties in its use are probably due more to inadequate mixing with digesta than to its physical properties themselves. 


\section{SUMMARY}

I. Two groups of three cows, consuming two different lots ( $S$ and $A$ ) of baled artificially dried grass, were given constant amounts of dried-grass cubes containing approximately $7 \cdot \mathrm{I} \%$ chromium sesquioxide $\left(\mathrm{Cr}_{2} \mathrm{O}_{3}\right)$ and $12.5 \%$ polyethyleneglycol (PEG) of molecular weight 4000 twice daily. One cow in each group consumed daily $\mathrm{I}_{4} \cdot 2 \mathrm{~g} \mathrm{Cr}_{2} \mathrm{O}_{3}$ and $25^{\circ} \mathrm{I} \mathrm{g} \mathrm{PEG}$, and the other four cows four times these quantities.

2. There was excellent agreement between the cows in each group in the coefficients of apparent digestibility of the dry matter of the ration. Recoveries of $\mathrm{Cr}_{2} \mathrm{O}_{3}$ in faeces were somewhat variable and over a 5 -day period averaged $97.2 \%$ of the amounts consumed by the six cows. Over the same period PEG recoveries averaged $96.0 \%$ for the three cows given dried grass $\mathrm{S}$ and $82.3 \%$ for the other group given dried grass $\mathrm{A}$.

3. It is concluded that the variable recoveries of $\mathrm{Cr}_{2} \mathrm{O}_{3}$, but not of $\mathrm{PEG}$, were due mainly to variations in the amounts present in the carrier cubes.

4. There was no evidence of absorption of PEG into the blood stream, and though some PEG may have been destroyed in the alimentary tract, the apparent low recoveries were probably due mainly to artifacts arising during analyses of faeces.

5. The patterns of excretion of $\mathrm{Cr}_{2} \mathrm{O}_{3}$ and $\mathrm{PEG}$ were studied in two $24 \mathrm{~h}$ periods. In all the cows the concentrations of $\mathrm{Cr}_{2} \mathrm{O}_{3}$ in the dry matter of separate defaecations varied by a maximum of approximately $\pm 10 \%$ from the $24 \mathrm{~h}$ weighted mean concentrations. Maximum variations in PEG concentrations, on a similar basis, were $\pm 40-60 \%$.

6. It is concluded that the uneven excretion in faeces arose mainly from uneven mixing with digesta in the reticulo-rumen and that the distinct patterns of excretion of the two substances arose from their differential distribution in this part of the gut. $\mathrm{Cr}_{2} \mathrm{O}_{3}$ was probably associated primarily with the solid fraction of the digesta and PEG with the liquid fraction.

We thank Dr A. Dobson of this Institute for several helpful suggestions.

This investigation was carried out with the aid of funds generously provided by the W. K. Kellogg Foundation, U.S.A. One of us (J.F.D. G.) was in receipt of a Research Studentship awarded by the Agricultural Research Council.

\section{REFERENCES}

Balch, C. C., Bartlett, S. \& Johnson, V. W. (r95 I). F. agric. Sci. 4r, 98.

Balch, C. C., Reid, J. T. \& Stroud, J. W. (1957). Brit. F. Nutr. I1, 184.

Barnicoat, V. R. (1945). N.Z.F. Sci. Tech. A, 27, 202.

Bloom, S., Jacobson, N. L., Allen, R. S., McGilliard, L. D. \& Homeyer, P. G. (1957). F. Dairy Sci. 40, 240.

Brisson, G. J., Pigden, W. J. \& Sylvestre, P. E. (r957). Canad. F. Anim. Sci. 37, 90.

Bullen, J. J., Scarisbrick, R. \& Maddock, A. (1953). F. Path. Bact. 65, 209.

Chanda, R., Clapham, H. M., McNaught, M. L. \& Owen, E. C. (195 I). F. agric. Sci. 4I, I79.

Corbett, J. L., Miller, T. B., Clarke, E. W. \& Florence, E. (1956). Proc. Nutr. Soc. 15, v.

Corbin, J. E. \& Forbes, R. M. (1951). F. anim. Sci. ro, 574.

Crampton, E. W. \& Lloyd, L. E. (195I). F. Nutr. 45, 3 I 9.

Eadie, J. M., Mann, S. O. \& Oxford, A. E. (1956). F. gen. Microbiol. r4, I22.

Hardison, W. A., Engel, R. W., Linkous, W. N., Sweeney, H. C. \& Graf, G. C. (1956). F. Nutr. 58, 11. 
Hardison, W. A. \& Reid, J. T. (1953). F. Nutr. 5r, 35.

Hardison, W. A., Linkous, W. N. \& Ward, C. Y. (1957). F. Dairy Sci. 40, 768.

Hoelzel, F. (1930). Amer. F. Physiol. 92, 466.

Hueper, W. C. (1941). Quoted by: Rennie, I. (1956). Proc. Nutr. Soc. 15, 6r.

Hydén, S. (1956a). LantbrHögsk. Ann. 22, 139.

Hydén, S. (1956b). LantbrHögsk. Ann. 22, 411 .

Kane, E. A., Jacobson, W. C. \& Moore, L. A. (1952). F. Nutr. 47, 263.

King, K. W. \& Moore, W. E. C. (1957). F. Dairy Sci. 40, 528.

Lambourne, L. J. (1957). F. agric. Sci. 48, 273.

Lancaster, R. J., Coup, M. R. \& Percival, J. C. (I953). N.Z. F. Sci. Tech. A, 35, I I7.

Moore, J. H. (1957). Brit. F. Nutr. I1, 273.

Oyaert, W. (1955). Studie van de wijziging der minerale en stikstofhoudende fractie van het voeder tijdens de passage doorheen de voormagen. Thesis, State University, Ghent.

Pigden, W. J. \& Brisson, G. J. (1956). Canad. F. agric. Sci. 36, 146.

Raymond, W. F. \& Minson, D. J. (1955). F. Brit. Grassl. Soc. 10, 282.

Schalk, A. F. \& Amadon, R. S. (1928). Bull. N. Dak. agric. Exp. Sta. no. 216.

Schürch, A. F., Lloyd, L. E. \& Crampton, E. W. (1950). F. Nutr. 4r, 629.

Shaffer, C. B. \& Critchfield, F. H. (1947a). Analyt. Chem. r9, 32.

Shaffer, C. B. \& Critchifield, F. H. (19476). F. Amer. pharm. Ass. Sci. Ed. 39, 340.

Shaffer, C. B., Critchfield, F. H. \& Carpenter, C. P. (1948). Amer. F. Physiol. 152, 93.

Sperber, I., Hydén, S. \& Ekman, J. (1953). LantbrHögsk. Ann. 20, 337.

Woodman, H. E. (1954). Bull. Minist. Agric., Lond., no. 48, I 3 th ed.

\title{
The amino-acid requirement of laying hens
}

\section{Minimal requirement levels of essential amino-acids: techniques and development of diet*}

\author{
By DEWEY JOHNSON, JR. AND HANS FISHER \\ Department of Poultry Science, Rutgers University, New Brunswick, New fersey
}

(Received 13 Fanuary 1958 -Revised 9 April 1958)

The objectives of previous studies from this laboratory were to develop a diet in which nitrogen was supplied as free amino-acids that would maintain egg production (Fisher \& Johnson, I956) and to determine those amino-acids essential for it (Johnson \& Fisher, 1956). In proceeding with the determination of the requirement for individual amino-acids it was necessary, in order to reduce all amino-acids to minimal levels, to consider the factors that influence the amino-acid requirement of a species.

$\mathrm{N}$ intake has been shown to influence the requirement of several amino-acids in diets containing protein. However, no direct information is available concerning the effect of the $\mathrm{N}$ intake as related to diets containing free amino-acids. The relationship between protein intake and caloric intake has been well established in chick nutrition and reports are beginning to appear concerning the relationship between dietary aminoacid level and energy intake.

* Paper of the Journal Series, New Jersey Agricultural Experiment Station, Rutgers University, the State University of New Jersey, Department of Poultry Science, New Brunswick.

Paper no. I: F. Nutr. (1956), 60, 26r. Paper no. 2: F. Nutr. (1956), 6o, 275. 